\title{
Financialization of Turkey Industry Sector
}

\author{
Iş1 Tellalbaşı ${ }^{1}$ \& Ferudun Kaya ${ }^{1}$ \\ ${ }^{1}$ Abant İzzet Baysal University, Bolu, Turkey \\ Correspondence: Ferudun Kaya, Abant İzzet Baysal University, Bolu, Turkey. Tel: 90-532-386-7266. E-mail: \\ kayaferudun@gmail.com
}

Received: May 6, 2013

Accepted: June 27, 2013

Online Published: July 9, 2013

doi:10.5430/ijfr.v4n3p127

URL: http://dx.doi.org/10.5430/ijfr.v4n3p127

\begin{abstract}
Financial markets in the world, especially for the last three decades, have been evolving significantly in terms of market volumes, operational intensity, institutional and regulations as well as the authorities governing them. The increase in operational volumes and the changing nature of financial markets, creations of new financial products; led to the increase of the importance of financial capital and how it affected day to day life directly became one of the most important theoretical problems. Thus, the transformation witnessed in the financial markets led to a new era, dubbed as "financialization". In this article, the financialization of companies listed in the Istanbul Stock Exchange's Industrial Index is analyzed using an econometric technique known as Generalized Method of Moments. The quantitative analysis has used two distinct methods to measure the relationship between firms' investments and their debts, financial profits, sales and financial payments, variables that constitute variables for measuring financialization. Both models revealed a negative relationship between higher financial benefits and amount of investments.
\end{abstract}

Keywords: financialization, mortgage crisis, generalized method of moments

\section{Introduction}

Financial statements are the final product of accounting process. Income statement provides data for investment and other decisions. Income measurement and financial position of an economic entity has always been a challenge for accounting standard setting bodies. The main purpose of financial reporting is to provide information for user groups, especially stockholders and creditors to assist them in making decisions. Financial statements (including notes) are the main instruments in conveying the information to the users of financial information.

2007-2008 mortgage crisis, namely the second big crisis in the history of capitalism, is directly related to the financialization of private incomes that are spared for the expenditures for housing, education, healthcare, pension, and insurance, or in other words; the increase of their occupation with the financial markets. Even though the gross domestic produced in the global economy is increasing in the last thirty years, the rate of economic growth is interrupted from time to time due to financial and economic crises. While growing criticisms suggest that the world economic order is expanding on an unstable, shortsighted, and unequal manner; this paper discusses the occurrence of the crisis which took the world economy under its influence since August 2007, around the financialization concept as the last stage of capitalism.

Financialization means the shifting of capital accumulation priorities by the firms from real investment activities to short term, risky, and high yielding financial assets, whereas it means that the increase in indebtedness of households due to easy borrowing through financial intermediaries who do not make any risk evaluation. Additionally, the creation of profits which are increasingly created in the financial markets by the non-financial corporations (NFCs) causes the reduction of funds that are available for fixed capital investments.

Financialization, which started in the U.S.A., rapidly grasped the world with the help of globalization. A façade of this transformation is formed by the movements of rapidly innovated new products and the dramatic enlargement of the financial sector, whereas the other side of this transformation the active and leading role of the financial actors in the economy by continuing to grow in the face of this situation. In that sense, growing importance of the financial sector seems to be an indicator of financialization.

On the one hand, the capital search of commercial companies were facilitated by qualitative and quantitative transformation of banks and other financial institutions during the financialization process, liberalization of capital movements, globalization and integration of financial markets; on the other hand commercial banks started to bear 
towards short term profit oriented credits, while giving up financial intermediation via lending financial capital to industrial and commercial institutions and concentrated on capturing personal incomes which they see as profit source.

As advanced capitalist economies rapidly financialized, during the occurrence of the bubble in the economy, it was clear that sources of financial profit were changed. These profits largely were; service fees, commissions, and financial incomes that are related to the financial transactions made by the banks for their own account. Additionally, these profits consist of personal income to some level and are largely dependent on the use of the savings of the people.

In this study, financialization as the last stage of capitalism is opened to discussion, in order to determine its place in the finance literature and also a quantitative model of financialization is developed for the case of Turkey in order to test the usability in application.

\section{The Concept of Financialization}

There is not a single definition of financialization, although the changes in the financial area can be considered as an indicator of financialization. However in its most widely accepted fashion, Paulre (2008) defines financialization as "the growing functionality of financial markets, market players and financial institutions in domestic and international economy" (Paulre, 2008: 187). According to Ertürk (2008), financialization is the occupation of non-financial corporations in the financial markets (Ertürk, 2008: 211). Esptein (2005) defines financialization as the growing importance of financial motives, financial markets, financial actors and institutions in domestic and international economy. Dore (2002) on the other hand, provides a larger perspective than Epstein's definition and asserts that financialization is the increase of the control of financial industry over total economic activity, the existence of financial controls in company management, inclusion of financial assets in total assets and especially in equity, and the influence of stock markets in company decisions along with stock markets being a determinant for fluctuations in the business cycle (Dore, 2002: 166-17).

Financialization, according to Palley (2007), is the process of financial markets, financial institutions, financial elite being more effective in economic policy and results. Fine (2008) defines financialization as non-financial corporations acting like market players in terms of management practices (Fine, 2008: 4). Bryan et al. (2006) points out to the growing prevalence of financial accounts and institutions in both private and social life, due to a transformation in the management strategy of the companies to achieve their goals, in order to reach out to competitive investors (Bryan et al., 2006: 32).

According to Harvey (2005) financialization is the qualitative change in finance's role in the economy, alongside with the change of economy in the area of finance (Harvey, 2005: 4). This change has strengthened the relations of non-financial sectors with finance. Harvey claims that financialization have also altered the nature of the relationship between developed and developing countries. The surge of capital towards developing countries forced these countries to build up their reserves, and this in turn financed the current account deficit of the U.S.A. This benefited the U.S.A. the most, as the exporter of dollar, an international means of payment. In short, this created a result where the poor is loaning the rich in the world economy (Harvey, 2007: 69).

Financialization also encompasses the deregulation of the financial sector, the expansion of new financial products, liberalization of the international capital movements, and increasing volatility in the foreign exchange markets. Stockhammer (2007) defines the financialization as a process where movement towards market-based financial systems, the emergence of the institutional investors as main players in the financial markets, and the change of the management mindset in both financial and non-financial corporations towards shareholder maximization occur as it progresses (Stockhammer, 2007: 2).

Stockhammer (2004), Crotty (2005), and Skott and Ryoo (2008) mostly concentrate of the macroeconomic consequences of financialization and they define this term as the transformation in the relationship between the financial and the non-financial markets. Froud et al. (2001) analyzes financialization on the micro level. These academicians investigate the effects of financial markets on the behavior of companies and individual by the analyses they developed around the concept of "coupon pool capitalism".

Arrighi (2003), Harvey (2007) and Lapavitsas (2009) provide a different angle in their critical studies of financialization in which they investigate the roots of financialization in the process of capital accumulation and point out to capitalism's crisis of over-accumulation. Lapavitsas (2009) shows the exploitative sides of finance and the transformation of the financial system and in short points out to the changing roles of banks as financial intermediaries in contemporary capitalism.

Agliette and Bretton (2001) focus on the stock markets as what they think of as the dominant power of the new financial system which shapes the regime of accumulation. Financial liberalization has been the most important 
institutional factor for regulators in transforming the regime of accumulation. Therefore, they focus on the change between the non-financial corporations and financial markets.

Krippner (2005) first explains why financialization is the symbol of the U.S. economy. Krippner presents this in detail using macro data. Crotty (2005) sees financialization as the main component of the global neoliberal regime and documents the financialization of non-financial sectors in U.S.A. from various angles; whereas Duménil and Levy (2005) in their similar works regarding France and U.S.A., call attention to the issues of deregulation and financial liberalization during the decline of the rate of profit. These works bring forth three important points. These are, the proportional increase of real investments of non-financial corporations in parallel with their financial investments, non-financial corporations earning a large share of their profits through financial transactions, and finally using again a large share of their income in financial markets to pay interest and dividends, or to buy back shares.

One of the important questions that needs to be asked, in the financialization literature, is that why is it that the period of financialization is defined as the post-1980s? Arrighi (1994, 2003, and 2005), Arrighi and Silver (1999), Harvey (2003), Sweezy (1997), Amin $(1996,2003)$ and Orhangazi (2008) attempted to provide an answer to this question, whereas mainstream-orthodox economics stayed silent. These works point out to deregulation and liberalization as lying in the roots of financialization, and largely relate the phenomenon to the crisis in the 1970s. Duménil and Levy (2005) stresses the importance of politics and class dynamics in the process of financialization.

Another debate is the macroeconomic dynamics of financialization in the U.S. economy. Boyer (2000), Aglietta and Breton (2000) attempt to understand these dynamics, whereas Stockhammer (2004) and Orhangazi (2008) associate the effects of capital accumulation of non-financial corporations (NFCs) in the U.S.A.

Additionally, the stage of financialization is characterized with the increase in inequality of income distribution and deterioration of the conditions of labor. Epstein and Jayadev (2005) document that the national income is more and more directed towards financial institutions and owners of financial assets and their share of the national income raised during 1980s and 1990s, by giving examples from OECD countries.

Froud (2001) associate financialization with coupon pool capitalism, and depicts that the coupons are either held by the households directly or indirectly via the pension funds or insurance companies in order to collect household income. This way households gain the ability to make financial investments via either joining their savings directly in a coupon pool or indirectly via professional fund managers.

Finally, the change in the international financial relations forms yet another part of the ongoing discussions. Explosion of international financial transformation, changes in the international monetary system and the sprouting of financial crises in developing countries causes finance to be extensively and deeply discussed (Babb, 2005; Akyüz and Boratav 2005; O'Connell, 2005; Crotty and Lee 2005). Blecker (2005) shows the effects of financialization on theories of international trade and finance. A number of works highlight the unsustainability of financialization in a global scale while discussing financial crises (D'Arista, 2005; Grabel, 2005; Felix, 2005).

Orhangazi (2008) defines financialization as process where non-financial corporations enter into financial activities followed by the reduction of profit rates due to crisis in 1970s, and investigates the effect of financialization on real sector investments. Mobilization of the change in the financial markets with deregulation helped non-financial corporations to engage in the financial area. Followed by this, the increase in the financial assets of non-financial corporations strengthened the financial sector and improved the financial investment opportunities. Preference towards the maximization of the short term profitability over long term investments by institutional investors not only contributed towards the growing numbers of participants in financial markets but also points out the change in corporate governance.

Contemporary finance reached its epitome by its adoption of "create and distribute" finance model (the creation, sale and distribution of various financial tools to investors by financial institutions) and the following "securitization of credit" (packaging of credits with other financial assets as marketable securities). Therefore, financialization consists of the provision of much needed funds by the real sector directly via capital markets in the form of finance capital instead of via intermediation of banks, as well as, the orientation of finance capital towards personal income, in Harvey's (2005) words, due to the transformation of the supporting role of finance, in order to survive.

\section{Econometric Analysis of the Relationship between Financialization and Capital Accumulation}

\subsection{Generalized Method of Moments (GMM)}

Generalized Method of Moments emerged with the work of Hansen (1982) where it is shown that time conditions can be used for the estimation of parameters in a consistent manner, under generally weak assumptions. Numerous 
standard estimators, including the Instrumental Variable Method (IV) and Ordinary Least Squares Method (OLS) are merely specific states of GMM.

Superiority of GMM is that its capability to formulate certain estimators and models without requiring strong distribution assumptions (Greene, 2005). Ingenuity of Hansen's work is to show how to make a selection among time condition estimators by allowing auto-correlation, multicollinearity and non-linear conditions (Wooldridge, 2001). GMM estimator is an effective method for large samples; however it is known that its small sample properties are weak. (Note 1)

GMM has certain superiorities over simple estimators under certain circumstances. In that sense, GMM's advantage lies in its allowance of over specification which means that the parameters of the model during estimation can be greater than the number of instrumental variables. It is general to use the Two Stage Least Squares Method (2SLS) in the case of over specification, however GMM estimator provides a more consistent estimator if auto-correlation exists.

\subsection{Dynamic Panel and GMM Estimation Technique}

It is common to use the generalized method of moments of Arellano and Bond (1991) in the estimation of panel model. Arellano and Bond (1991) creates the moment conditions by assuming that the future values of the error and the current values of the explanatory variables are not correlated. Error term does not embody serial correlation and is homoscedastic. Explanatory variables are not correlated with unobservable firm specific effect, which is unit effect. Arellano and Bond (1991) suggest the use of a two stage GMM estimator, in the case that the error term is heteroscedastic. In the first stage of the estimation, it is assumed that the error term is homoscedastic with both independent and explanatory variables against time. This assumption is stretched, when a consistent estimation of the variance-covariance matrix formed using the errors obtained in the first stage. It is seen that the two stage GMM estimator is more effective when the error term is heteroscedastic.

The nature of many economic relations is dynamic and one of the advantages of the panel model is that it allows researcher to better understand dynamic relations. Dynamic relations are characterized by the existence of a dependent variable within the regressors. As an example (Duch, 2008);

$$
Y_{j t}=\vartheta Y_{j t-1}+\phi Z_{j}+{ }_{y} X_{j t} \theta_{j t}+\theta_{j}+\varepsilon_{j t}
$$

$\mathrm{j}=1,2,,{ }_{,},{ }_{,},{ }_{,},, \mathrm{N}, \mathrm{t}=1,2,,,{ }_{,},{ }_{,},, \mathrm{T}$

$\theta_{j}$ shows the unit effect.

$Z_{j}$ consists of additional explanatory variables which do not change over time.

$\mathrm{X}_{\mathrm{jt}}$ is the explanatory variable where causality is investigated.

All explanatory variables level is exogenous.

$\varepsilon_{\mathrm{jt}}$ has zero mean, fixed variance and independent distribution.

OLS estimations are biased, because correlation exists between the lagged endogenous variable $\left(\mathrm{y}_{\mathrm{jt}-1}\right)$ and unit effects $\left(\theta_{\mathrm{j}}\right)$ : where affects $\varepsilon_{\mathrm{jt}}, Y_{j t} y i$ as well as it affects $Y_{j t-1}$.

In the case of the use of lagged dependent variables in fixed effect and random effect models, there may emerge serious problems due to the correlation between lagged dependent variable and the error term. Therefore, there exist differences between dynamic panel models and fixed or random effect models (Grene, 2000).

Variability between groups is removed from the fixed or random effect model when the first differences are taken; however the model becomes as follows (Duch, 2008):

$$
Y_{j t}-Y_{j t-1}=\vartheta\left(Y_{j t-1}-Y_{j t-2}\right)+\sum_{k} \beta_{k}\left(X_{k j t}-X_{k j t-1}\right)+\left(\varepsilon_{j t}-\varepsilon_{j t-1}\right)
$$

Therefore, correlation problem between the lagged dependent variables $\left(\mathrm{Y}_{\mathrm{jt}-1}-\mathrm{Y}_{\mathrm{jt}-2}\right)$ and $\left[(\varepsilon)_{\mathrm{jt}}-\varepsilon_{\mathrm{jt}-1}\right]$ occurs.

In this case, it is suggested that some instrumental variables are needed for the parameter estimations of the lagged dependent variable $(\vartheta)$. Anderson and Hsiao (1981) point out that lagged dependent variables with different lag

levels such as, $\mathrm{Y}_{\mathrm{jt}-1}-\mathrm{Y}_{\mathrm{jt}-2}$ or $\mathrm{Y}_{\mathrm{jt}-2}$ or $\mathrm{Y}_{\mathrm{jt}-3}$, are in correlation with instrumental variables for $\left(\mathrm{Y}_{\mathrm{jt}-1}-\mathrm{Y}_{\mathrm{jt}-2}\right)$, but they will not be correlated with the error term. Since the IV method, which is suggested for the estimation of the 
dynamic panel model, will not be effective as it does not allow the use of the probability of the all moment conditions and ignore the difference structure of the error term $\left(\Delta \varepsilon_{\mathrm{jt}}\right)$. Arellano and Bond (1991) points out to the use of some but not all the possible instrumental variables, as the cause of such problem. Arellano and Bond (1991), therefore, developed the GMM by suggesting the use of all the valid lagged variables as instrumental variables in dynamic panel data models. This way, GMM allows for the use of all the instrumental variables to provide orthogonality constraints and also a non-parametric estimator of the covariance matrix is being used. The model now becomes as follows:

$$
\mathrm{Y}_{\mathrm{jt}}-\mathrm{Y}_{\mathrm{jt}-1}=\vartheta\left(\mathrm{Y}_{\mathrm{jt}-1}-\mathrm{Y}_{\mathrm{jt}-2}\right)+\sum_{\mathrm{k}} \beta_{\mathrm{k}}\left(\mathrm{X}_{\mathrm{kjt}}-\mathrm{X}_{\mathrm{kjt}-1}\right)+\sum_{\mathrm{s}} \beta \phi_{\mathrm{s}}\left(\mathrm{W}_{\mathrm{sjt}}-\mathrm{W}_{\mathrm{sjt}-1}\right)+\left(\varepsilon_{\mathrm{jt}}-\varepsilon_{\mathrm{jt}-1}\right)
$$

\section{$\mathrm{X}_{\mathrm{kjt}}$ : Exogenous covariates}

$\mathrm{W}_{\mathrm{sjt}}$

\section{: Predetermined or endogenous covariates}

Instrumental variables are used for the estimations of the lagged endogenous variable parameters $(\vartheta)$ and also first difference equations are taken as equation 3 above shows.

The final form of the GMM estimation of $\beta$ is as follows (Duch, 2008):

$$
\hat{\beta}=\left(X^{\prime} Z \widetilde{W} Z^{\prime} X\right)^{-1}\left(X^{\prime} Z \widetilde{W} Z^{\prime} Y\right)
$$

$Z$ : included the instrumental variables in the difference equations.

GMM type instrumental variables, predetermined and endogenous covariates of $\mathrm{W}_{\mathrm{sit}}$ are lagged variables. Standard instruments are the first difference of the exogenous variables of $\mathrm{X}_{\mathrm{kjt}}$.

\section{Definition of Variables}

The model that is used for the corporations that are operating in the industrial sector of Turkish Istanbul Stock Exchange (ISE) is based on the financialization model that Orhangazi (2008) uses for U.S.A. Since the assumptions of Orhangazi's model can be supported in terms of economics and the fact that the economic impacts are imported by the countries due to financial globalization supports the idea to use Orhangazi's model in Turkey's case and do not create differences in analysis.

In this study, the factors that define financialization for 132 corporations are empirically explored. The effects of financialization on the corporations that are traded in the ISE Industrial Index consistently between 2005 and 2010 are investigated. Data that is related to the ISE Industrial Index (XUSIN) are obtained via ISE financial statements section and public disclosure platform. Financial corporations, financial institutions, investment companies, holdings with financial subsidiaries in the industrial index, and corporations that are removed from the ISE Industrial Index are excluded from this study. The reasons for the $2005-2010$ period of this study as follows; firstly the number of cross section data is smaller before 2005 and secondly Turkey switched to the TMS-IFRS system after 2005.

Data related to the corporations are obtained from financial statements section and public disclosure platform in ISE's official web site. Statistical analysis is done by EViews 5.0 software.

\section{The Modeling of the Indicators of Financialization}

In this study, where the factors that are thought to have an effect on financialization are investigated with a dynamic panel data model, investments are taken as dependent variable, whereas profits, sales, short and long term debt, financial expenditures and payments, financial income and the ratio of profits to fixed assets are defined as independent variables. The aim of taking the ratio of profits to fixed assets is to answer the question whether the funds that are used by the corporations in financing investments are coming from internal resources or external resources. Additionally, independent variables are determined on the basis of availability and the existing literature. The main model that is used in this study, a model that is formed by using dynamic panel data model, is as follows.

\subsection{Model I}

$\alpha_{1} \ldots \alpha_{5}$ are the parameters where $i$ represents the firm and $t$ represents time. $I$ is total cash that is used in investment activities, $K$ is total fixed assets, $\pi$ total operational profit, $S$ total sales, $D$ total debt, $\pi^{\mathrm{F}}$ total financial income, $P$ total interest and dividend payments, and finally $\varepsilon_{\text {it }}$ represents random error term. 


\subsection{Model II}

$\alpha_{1} \ldots \alpha_{5}$ are the parameters where $i$ represents the firm and $t$ represents time. $I$ is total cash that is used in investment activities, $K$ is total fixed assets, $\pi$ total operational profit, $S$ total sales, $D$ total debt, $\pi^{\mathrm{F}}$ total financial income, $P$ total interest and dividend payments, and finally $\varepsilon_{\text {it }}$ represents random error term.

$$
\alpha_{1}>0, \alpha_{2}>0, \alpha_{3} \gtrless 0, \alpha_{4}<0, \alpha_{5}<0
$$

In the testing phase of the model, financialization variables, namely total financial income and total interest and dividend payments, are expected to have a negative effect on investments, whereas the effect of the other variables such as, total operational profit, total sales, profit rate and production, is expected to have a positive effect on investments. Debt might have either a positive or a negative effect on real sector investments. For example, when the borrowing costs are low, corporations may very well prefer to borrow from the financial markets instead of using internal resources.

In this model, financialization is aimed to be tested through the effects of and $\mathrm{P}$ variables, while other determinants of NFC investments are controlled. Initially, the increase of financial investments and financial profits are going to create a crowding out effect, which in turn will lead managers to divert their funds from real investments towards financial markets with an aim to gain income. Secondly, while financial payments are going to reduce equity, which in turn will have a negative effect on real investments and increase uncertainty. In Orhangazi's corporation based GMM analysis of U.S.A. payments to the financial markets has a negative effect on investments, which is similar in the case of Turkey as well.

\section{Determinants of Investments and Financialization}

Ultimate purpose of this research is to measure the effects of financialization on capital accumulation. Capital accumulation has an amplifying effect on the real sector investments. The most important tenet of the capitalist system has an unignorable effect on investments. Therefore, the aim of this section first is to define and explain the variables of investment.

\subsection{Profitability and Demand}

It is widely discussed that the main driver behind the success of a corporation is not simply growth but rather profitability; and growth without profitability not necessarily might not lead to financial success. Corporations' growth rates are closely connected to supply and demand conditions. Corporations, ceteris paribus, evaluate potential investment projects on the basis of their profitability and the risk involved, since profitability is the main important factor for corporations. It is observed in our financialization hypothesis that the coefficient of profitability is positive and statistically significant.

According to the theory of financial hierarchy (Note 2), corporations with a priority of internal financing, when it is profitable, are unlikely to borrow compared to other corporations. This theory, which expects that borrowing decision is likely to diminish as profitability rises, points to a negative relationship; whereas the balancing theory suggests the opposite arguing that firms, which experience higher profitability, will increase borrowing in order to benefit from the tax shield.

\subsection{Financial Payments}

Financial payments can be described as the total of the interest and dividend payments arising due to the corporations' transactions in the financial markets. In our model it is expected that there exists a negative relationship between financial payments and investments. High amounts of financial payments are and indicator that the corporation is fading away from real investments and also high amounts of financial payments may very well create profitability and liquidity problems for the corporation as well. Financialization theory expects a negative sign for the financial payments variable and is statistically significant as can be seen in Table 2 and Table 3 . It can be said that the financial payments, as a financialization variable explained above, has a detrimental effect on the real sector investments in Turkey.

One of the biggest problems of the corporations is indebtedness. The purpose of using indebtedness as a variable is that indebtedness increases financial fragility and thereby has a negative effect on corporations' investments. Investment financing is generally raised via money markets instead of capital markets in countries with low capital accumulation like Turkey.

Model I and Model II shows that the long term debt variable has a positive but a little effect on investment behavior of NFCs. Generally the ratio of long term debt to capital has a limitation effect on the real sector investment behavior. However, according to the statistical results indebtedness variable has a significant effect on investments. The reason 
for this is that capital accumulation is inadequate as mentioned above.

\subsection{Financial Income and Profits}

Financial income and profits consist of non-operational profits and income that corporations obtain in financial markets. One of the reasons to lead corporations towards seeking financial profits and income is that real investments are long term and subject to high risk. This directs corporations towards looking for gaining short term income and profits. Therefore, financial profits and income are expected to have a negative effect on investments. Financial profits and income variable is negative and statistically significant in our model. Financial profits and income variable is negative and statistically significant in terms of NFCs as these do not have support over the past investments. Therefore short term financial profits and income lead to transformation in NFCs managerial decisions and negatively affect real sector investments.

\subsection{Sales Revenue}

Purpose of corporations is to achieve sustainable growth and obtain profits. Sales, which is critical, defines the future of the corporations. Profits that are going to be obtained by the corporation is directly connected to the sales. However, sometimes corporations concentrate on sales rather than profitability. While Increasing sales lead to shrinking unit costs, it results in a positive relationship between corporation size and profitability.

However, almost daily advancement of technology leads to the reduction of the life cycles of the firms, whereas new rival corporations apply aggressive policies which lead to a reduction in sales revenue. Reduction in sales revenue leads to an increase in unit costs and fuel anxiety about the future, thereby negatively affect investments of corporations. Corporations, as a reaction to such process, start to look for alternative mechanisms of profit generation. The deepening of financial markets and the increase in the variety of financial instruments feed this sort of mechanism of profit generation as well, and places owners of corporations as players in financial markets. The effect of sales revenue as can be seen in our model is very limited yet still statistically significant, it is therefore safe to say that sales revenue does not have an effective role on investments of NFCs.

Statistical results suggest that NFCs in Turkey act with the aim of gaining the profits in financial markets, which they could not via sales revenue.

Table 1. Descriptive statistics

\begin{tabular}{ccccc}
\hline Variable & No. of Observations & Mean & Minimum & Maximum \\
\hline $\mathrm{I} / \mathrm{K}$ & 6 & 0.023 & 0.016 & 0.792 \\
$\pi / \mathrm{K}$ & 6 & 0.032 & -0.031 & 0.112 \\
$\mathrm{~S} / \mathrm{K}$ & 6 & 0.451 & 0.049 & 0.172 \\
$\mathrm{D} / \mathrm{K}$ & 6 & 0.188 & 0.016 & 0.684 \\
$\mathrm{P} / \mathrm{K}$ & 6 & 0.074 & 0.368 & 0.330 \\
$\pi^{\mathrm{F}} / \mathrm{K}$ & 6 & 0.227 & 0.029 & 0.122 \\
\hline
\end{tabular}

Table 2. Model I

\begin{tabular}{|c|c|c|c|c|}
\hline \multicolumn{5}{|l|}{ Dependent Variable: INV2 } \\
\hline \multicolumn{5}{|c|}{ Method: Panel Generalized Method of Moments } \\
\hline \multicolumn{5}{|l|}{ Transformation: First Differences } \\
\hline \multicolumn{5}{|l|}{ Date: 06/06/11 Time: $19: 43$} \\
\hline \multicolumn{5}{|l|}{ Sample (adjusted): 20072010} \\
\hline \multicolumn{5}{|l|}{ Cross-sections included: 132} \\
\hline \multicolumn{5}{|l|}{ Total panel (unbalanced) observations: 505} \\
\hline \multicolumn{5}{|c|}{ White period instrument weighting matrix } \\
\hline \multicolumn{5}{|c|}{ White period standard errors \& covariance (d.f. corrected) } \\
\hline \multicolumn{5}{|c|}{ Convergence not achieved after 500 weight iterations } \\
\hline \multicolumn{5}{|c|}{ Instrument list: @DYN(INV2,-2)DEBT(-1) FINPROFIT(-1) PROFIT(-1)P SALES(-1)@SYSPER } \\
\hline Variable & Coefficient & Std. Error & t-Statistic & Prob. \\
\hline INV2(-1) & $0.624275^{* * *}$ & 0.003852 & 1.620 .549 & 0.0000 \\
\hline DEBT(-1) & 0.013769 & 0.009781 & 1.407 .709 & 0.1598 \\
\hline FINPROFIT(-1) & $-0.049034 * * *$ & 0.018685 & -2.624 .257 & 0.0090 \\
\hline PROFIT(-1) & 0.004245 & 0.016896 & 0.251255 & 0.8017 \\
\hline
\end{tabular}




$\begin{array}{rcccc}\text { P } & -0.047736^{*} & 0.025966 & -1.838 .403 & 0.0666 \\ \text { SALES(-1) } & 0.006666^{*} & 0.003894 & 1.711 .843 & 0.0876 \\ \text { @ISPERIOD("2007") } & -0.015637 & 0.011937 & -1.309 .988 & 0.1908 \\ \text { @ISPERIOD("2008") } & -0.039553 * * * & 0.011920 & -3.318 .294 & 0.0010 \\ \text { @ISPERIOD("2009") } & -0.075203^{* * *} & 0.014328 & -5.248 .600 & 0.0000 \\ \text { @ISPERIOD("2010") } & -0.036177^{* *} & 0.015221 & -2.376 .795 & 0.0178\end{array}$

Effects Specification

Cross-section fixed (first differences)

Period fixed (dummy variables)

$\begin{array}{rrrr}\text { R-squared } & 0.433778 & \text { Mean dependent var } & -0.014493 \\ \text { Adjusted R-squared } & 0.459846 & \text { S.D. dependent var } & 1.946 .489 \\ \text { S.E. of regression } & 2.351 .828 & \text { Sum squared resid } & 2.737 .892 \\ \text { J-statistic } & 3.561 .606 & \text { Instrument rank } & 1.900 .000\end{array}$

Note: $(1) *$ significant at $10 \%, * *$ significant at $5 \%, * * *$ significant at $1 \%$

(2) Logarithmic values are used in Orhangazi's GMM model for U.S.A. However, since there exist many negative values in the balance sheet figures of corporations in Turkey, it was not possible to use logarithmic values in this model.

Table 3. Model II

\begin{tabular}{|c|c|c|c|c|}
\hline \multicolumn{5}{|l|}{ Dependent Variable: INV2 } \\
\hline \multirow{2}{*}{\multicolumn{5}{|c|}{$\begin{array}{l}\text { Method: Panel Generalized Method of Moments } \\
\text { Transformation: First Differences }\end{array}$}} \\
\hline & & & & \\
\hline \multicolumn{5}{|c|}{ Date: $06 / 06 / 11 \quad$ Time: $19: 51$} \\
\hline \multicolumn{5}{|c|}{ Sample (adjusted): 20072010} \\
\hline \multicolumn{5}{|c|}{ Cross-sections included: 132} \\
\hline \multicolumn{5}{|c|}{ Total panel (unbalanced) observations: 505} \\
\hline \multicolumn{5}{|c|}{ White period instrument weighting matrix } \\
\hline \multicolumn{5}{|c|}{ White period standard errors \& covariance (d.f. corrected) } \\
\hline \multicolumn{5}{|c|}{ Convergence not achieved after 500 weight iterations } \\
\hline \multirow{2}{*}{\multicolumn{5}{|c|}{ Instrument list: @DYN(INV2,-2) DEBT(-1) FINPROFIT(-1) PROFIT(-1) }} \\
\hline P@SYSPER & & & & \\
\hline Variable & Coefficient & Std. Error & t-Statistic & Prob. \\
\hline INV2(-1) & $0.630290^{* * *}$ & 0.003673 & 1.715 .890 & 0.0000 \\
\hline DEBT(-1) & $0.021565^{* *}$ & 0.008941 & 2.411 .823 & 0.0162 \\
\hline FINPROFIT(-1) & $-0.045020 * *$ & 0.018080 & -2.489 .976 & 0.0131 \\
\hline PROFIT(-1) & 0.012183 & 0.016147 & 0.754465 & 0.4509 \\
\hline $\mathrm{P}$ & $-0.049063^{*}$ & 0.026069 & -1.882 .016 & 0.0604 \\
\hline @ISPERIOD("2007") & -0.014273 & 0.012100 & -1.179 .607 & 0.2387 \\
\hline @ISPERIOD("2008") & $-0.036728 * * *$ & 0.011715 & -3.135 .264 & 0.0018 \\
\hline @ISPERIOD("2009") & $-0.075095 * * *$ & 0.014419 & -5.208 .065 & 0.0000 \\
\hline @ISPERIOD("2010") & $-0.037292 * *$ & 0.015620 & -2.387 .429 & 0.0173 \\
\hline \multicolumn{5}{|l|}{ Effects Specification } \\
\hline \multicolumn{5}{|c|}{ Cross-section fixed (first differences) } \\
\hline R-squared & 0.443029 & Me: & endent var & -0.014493 \\
\hline Adjusted R-squared & 0.466304 & & endent var & 1.946 .489 \\
\hline S.E. of regression & 2.357 .024 & & uared resid & 2.755 .558 \\
\hline J-statistic & 3.841 .951 & & iment rank & 1.800 .000 \\
\hline
\end{tabular}

Note: $(1) *$ significant at $10 \%, * *$ significant at $5 \%$, *** significant at $1 \%$ 


\section{Evaluation of Econometrical Estimation Results}

In both models (Model I and Model II), where we attempt to explain financialization, investment ratio is analyzed as the dependent variable. Models are estimated using the technique of "Generalized Method of Moments" by Arellano and Bond. First version of the investment model includes sales as an independent variable, which is missing in the second model. In addition to that, dummy variables are used in order to observe factors that are time-specific.

Coefficient and adjusted coefficient of determination $\left(\overline{\mathrm{R}}^{2}, \mathrm{R}^{2}\right)$ of the models, when considered as a whole, can explain the change in the dependent variable 43,3 percent at minimum and 46 percent at maximum. Even though the number of independent variables in Model I are one more than the number of independent variables in Model II, it is observed that this does not have an increasing effect on the coefficient of determination. Therefore, parallel to other studies in the literature, it is seen appropriate to choose economically viable independent variables only, although the discussion of incorporating additional explanatory variables in the model arises.

A negative correlation between the independent variable financial profits (FINPROFIT) and the dependent variable investment ratio (INV2) was identified in Model I. When the t-statistic of this variable considered alone, it can be argued that it has a statistically significant contribution towards explaining the dependent variable.

It can be argued that the use of panel data along with the use of generalized method of moments as the estimator in the model, combined with the signs of the coefficients between the dependent and independent variables being are parallel to the signs of coefficients that can be found in the literature is positive in terms of the success of the model.

Model II presents a coefficient of determination value that is parallel to Model I, in terms of explanatory power. However in Model II, when the t-statistics of independent variables DEBT and FINPROFIT are taken individually, it can be argued that these dependent variables present an explanatory power that is statistically significant.

In both models, increase in the profits and indebtedness levels of corporations contribute positively to the investment ratio. At his point, the relationship between financial profits and investment ratio is found to be a negative one. Therefore, it can be argued that financial profit has a reduction effect on investment motives in real sector. While operational profitability affects investment positively, financial profit on the other hand, which is considered to be a non-operational income for NFCs, reduces the investment motive, within the estimated parameters of the model.

When a general evaluation of the quantitative results of the model in the context of Turkey's economy and financial system, it is seen that NFCs are obtaining non-operational profits due to financialization which in turn causes a reduction in the real sector investment trend and therefore negatively affect the process of capital accumulation. Policy implication of this process might be the further increase in financialization which will have a further detrimental effect on real investments and capital accumulation.

Statistical results indicate that while indebtedness of corporations in ISE Industrial Index is rising, their investments are also increasing. The results of the financialization model that is initially applied for U.S.A. are also supported in the case of Turkey based on the statistical analysis made. In short, financialization has negative effects on investments, as well as is detrimental to the process of capital accumulation. On the other hand, financialization enables the generation of artificial profits for NFCs and causes them to deviate from production activities.

\section{Summary and Concluding Remarks}

Crisis of $2007=2008$ is the deepest crisis that has happened in the history of capitalism since the Great depression of 1929. The role played by financialization in this crisis distinguishes it from the others. Literature research led to the observation that financialization has detrimental effects on economic growth and capital accumulation. It is also observed that the start of the era of financialization is coming right after the neoliberal era.

Financialization hypothesis, as the main subject of this research, is discussed in terms of advanced capitalist economies with a developed financial system. However, considering the point at which financial liberalization and globalization came to, financialization is thought to be carrying a possible relevancy regarding the developing world. This is due to two reasons first is that the financial systems of developing countries which are implementing financial liberalization has been increasingly become similar to financial systems of advanced capitalist countries and second is that these countries cannot sterilize themselves from the global economy due to globalization. Similarly the financial system in Turkey's economy after 1980s has been subjected to a series of important reforms and started to become similar to the systems in advanced capitalist economies. It can be argued that this similarity of the financial system in Turkey might be responsible for the emergence of the elements that create financialization. Development of the financial system can be attributed to the deepening of financial markets and the increase in the variety of the 
financial markets. In that sense, it can be argued that the financial system in pre-1980s Turkey was shallow and under the control of the state, however with the reforms after 1980 it has gained depth and a variety of financial instruments. The purpose of these reforms was, with the liberalization of the financial system, to increase the efficiency of aggregate savings and investments, as well as the financial system in general. These policies had limited success regarding their initial purposes, but at the same time started to transform the financial system on the image of developed economy financial systems. This transformation to a degree also brought the question of whether the observed instability is due to the financial system. The answer to such a question lies within the testing of the financialization hypothesis in the Turkey's setting. However, this kind of a test has its own peculiarities, thus it is seen that the financialization hypothesis is not widely tested, as suggested by the missing literature on the issue. This is partly due to the fact that financialization does not belong to a specific school of economic thought, and is simply that this kind of analysis has never been applied in the case of Turkey. In this context, the relationship that this research concentrates upon is the dependency of NFCs to finance capital and the negative effect of financialization variables on capital accumulation process and real sector investments of the NFCs.

As mentioned earlier, real sector is deviated from fixed capital investments due to financialization and is seeking income via speculative transactions in financial markets. While deregulation lifted the limitations on such corporations, whereas the explosion of various exotic financial instruments due to financial innovation has contributed to the further deepening of these financial markets. Although financialization is a new concept in the economic literature, widely shared idea that is reached statistically is that financialization has a negative effect on investments and capital accumulation. Therefore, profits, financial payments, sales, financial profits, and debt of corporations are incorporated in the model. GMM technique is used for testing as it allows a better understanding of dynamic relations within the economy, which is also widely employed by other studies in the literature. Relations between variables in the period between 2005 and 2010 were analyzed and it is seen that these relations coincide with the relations that financialization hypothesize. As a result, in both models the increasing levels of profitability and indebtedness of corporations are positively contributing to the growth of fixed investments of the real sector. However, the relationship between financial profits and investments are found to be negative in both models as well. At this point, it can be said that the growth of financial income and profits and financial expenditures and payments has a negative effect on real sector investments and is detrimental to capital accumulation.

As a conclusion, when Turkey's economy is evaluated on the basis of financialization, it can be argued that NFCs started to obtain non-operational profits due to financialization, and as this type of profitability has risen it affected the process of capital accumulation negatively by reducing investment trends. This study also shows that, financialization can show cyclical volatility depending on private sector investment and financing decisions.

\section{References}

Aglietta, M. (2000). Shareholder Value and Corporate Governance: Some Tricky Questions. Economy and Society, 29(1), 146-59. http://dx.doi.org/10.1080/030851400360596

Aglietta, M., \& R. Breton. (2001). Financial Systems, Corporate Control and Capital Accumulation. Economy and Society, 30(4), 433-66. http://dx.doi.org/10.1080/03085140120089054

Akdiş, M. (2000). Global Sistem, Finansal Krizler ve Türkiye. Beta Yayın, İstanbul.

Aktan, C, C., \& ve H. ŞEN. (1999). Globalleşme, Ekonomik Kriz ve Türkiye. TOSYÖV Yayınları, Ankara.

Akyüz, Y. (2000). Financial Liberalization: The Key Issues. UNCTAD Discussion Papers, No: 56.

Akyüz, Y. (2000). Managing Financial Instability and Shocks. İktisat, İşletme ve Finans Dergisi, Say1: 219.

Akyüz, Y., \& K.Boratav. (2005). The Making of the Turkish Crisis. In G. Epstein (Ed.), Financialization and the World Economy. Cheltenham, UK and Northampton, MA, USA: Edward Elgar.

Arellano, M., \& S. Bond. (1991). Some Tests of Specification for Panel Data: Monte Carlo Evidence and an Application to Employment Equations. Review of Economic Studies, 58(2), 227-297. http://dx.doi.org/10.2307/2297968

Blecker, R. (2005). Financial Globalization, Exchange Rates and International Trade. In G. Epstein (Ed.), Financialization and the World Economy (pp. 183-219). Cheltenham, UK and Northampton, MA, USA: Edward Elgar.

Boratav, K., \& ve Y. Akyüz. (2002). Türkiye'de Finansal Krizin Oluşumu. İktisat İşletme ve Finans Dergisi, Sayı: 197. 
Boyer, R. (2000). Is a Finance-led Growth Regime a Viable Alternative to Fordism? A Preliminary Analysis. Economy and Society, 29(1), 111-45. http://dx.doi.org/10.1080/030851400360587

Bryan, D., \& M. Raffertty. (2006). Capitaism With Derivatives- A Political Economy of Financial Derivatives, Capital and Class. New York.

Chang, R. (1999). Understanding Recent Crises in Emerging Markets. Economic Review, Federal Reserve Bank of Atlanta, Second Quarter.

Crotty, J. (2005). The neoliberal paradox: the impact of destructive product market competition and modern financial markets on non-financial corporation performance in the neoliberal era. In G. Epstein (Ed.), Financialization and the World Economy, Cheltenham, UK and Northampton (pp. 77-110). MA, USA: Edward Elgar.

Crotty, J., \& K. Lee. (2005). Economic performance in post-crisis Korea: a critical perspective on neoliberal restructuring. In G. Epstein (Ed.), Financialization and the World Economy (pp. 334-53). Cheltenham, UK and Northampton, MA, USA: Edward Elgar.

D' Arista, J. (2005). The Role of the International Monetary System in Financialization. In G. Epstein (Ed.), Financialization and the World Economy (pp.220-39). Cheltenham, UK and Northampton, MA, USA: Edward Elgar.

Demir, F. (2005). Three Essays on Financial Liberalization, Country Risk And Low Growth Traps In Argentina, Mexico and Turkey. Phd Thesis, Graduate Program in Economics, Notre Dame.

Demir, F. (2007). Private Investment, Portfolio Choice and Financialization of Real Sectors in Emerging Markets. University of Oklahoma, MPRA Paper No. 3835, November.

Dore, R. (2002). Stock Market Capitalism and its Discussion. New Political Economy, 7(1), 115-21. http://dx.doi.org/10.1080/13563460120115543

Drobetz, W., \& R. Fix. (2003). What are the Determinants of the Capital Structure? Some Evidence for Switzerland. WWZ/Department of Finance, Working Paper No. 4/03.

Duch, R. (2008). Longitudinal/Panel Data Analysis: Lecture 3 and 4. Retrieved May 8, 2011, from raymondduch.com/class/paneldata

Duménil, G., \& ve D. Lévy. (2005). Costs and Benefits of Neoliberalism: A Class Analysis. In Epstein, G. (Der.) (Ed.), Financialization and the World Economy. Northampton, US: Edward Elgar.

Duménil, G., \& ve Lévy, D. (2003). Periodizing Capitalism: Technology, Institutions, and Relations of Production. Retrieved August 18, 2010, from www.jourdan.ens.fr/levy

Eichengreen, B. (1996). Globalizing Capital, A History of the International Monetary System. New Jersey: Princeton University Press.

Eichengreen, B. (1999). Toward a New International Financial Architecture: A Practical Post-Asia Agenda. Washington, DC: Institute for International Economics.

Epstein, G. (2005). Financialization and the World Economy. Cheltenham, UK and Northampton, MA, USA: Edward Elgar.

Ertürk, İ., J. Froud, S. Johal, A. Leaver, \& K. Williams. (2008). Financialization at Work: Key Texts and Commentary. London; New York: Routledge.

Felix, D. (2005). Why international Capital Mobility Should Be Curbed and How It Could Be Done. In G. Epstein (Ed.), Financialization and the World Economy (pp. 384-408). Cheltenham, UK and Northampton, MA, USA: Edward Elgar.

Fine, B. (2008). From Financialisation To Neo-Liberalism: Engaging Neo-Liberalism. (School of Oriental and African Studies, University of London). Retrieved February 3, 2011, from http://www4.fe.uc.pt/ciclo_int/doc_08_09/02_holly_book_con.pdf

Frame, W. S., \& L. J. White. (2004). Empirical Studies of Financial Innovation: Lots of Talk, Little Action? Journal of Economic Literature, 42(1), 116-144. http://dx.doi.org/10.1257/002205104773558065

Froud, F., C. Haslam, S. Johal, \& K. Williams. (2000). Shareholder Value and Financialization: Consultancy Promises, Management Moves. Economy and Society, 29(1), 80-110. http://dx.doi.org/10.1080/030851400360578 
Froud, J., C. Haslam, S. Johal, \& K. Williams. (2001). Financialisation and the Coupon Pool. Gestao \& Producao, 8(3), 271-288, University of Manchester. http://dx.doi.org/10.1590/S0104-530X2001000300005

Grabel, I. (2005). Averting crisis? Assessing Measures to Manage Financial Integration in Emerging Economies. In G. Epstein (vd) kitap bolumu, Financialization and the World Economy, Cheltenham, UK and Northampton, MA, USA: Edward Elgar, pp. 357-83.

Greene, W. H. (2002). Economic Analysis ABD. Prentice Hall, 2002.

Hansen, P. L. (1982). Large Sample Properties of Generalized Method of Moments Estimators. Econometrica. Journal of the Econometric Society, 50(4), 1029-54. http://dx.doi.org/10.2307/1912775

Harvey, D. (2004). The Condition of Postmodernity: An Enquiry into the Origins of Cultural Change. First published in 1990 by Blackwell Publishing Ltd. USA.

Harvey, D. (2005). A Brief History of Neoliberalism. Oxford, Oxford University Press.

Hasio, C. (2002). Analysis of Panel Data. New York: Cambridge University Press. Horne 1985.

Henwood, D. (1997). Wall Street. New York: Verso.

Henwood, D. (2003). After the New Economy. New York: New Press.

Heywood, A. (2007). Politics. New York: Palgrave Macmillan Press.

İMKB, Mali Tablolar (Year of 2009 and before). Retrieved April 14, 2011, from http:/www.imkb.gov.tr/FinancialTables/companiesfinancialstatements.aspx?sflang=tr

KAP (Kamuyu Aydınlatma Platformu). Retrieved April 15, 2011, from http://www.kap.gov.tr/yay/ek/index.aspx

Kotz, D. M. (2008). Neoliberalism and Financialization. Political Economy Research Institute, University of Massachusetts Amherst, March 29, U.S.A.

Krippner, G. (2005). The Financialization of the American Economy. Socio-Economic Review, 3(2), $173-208$. http://dx.doi.org/10.1093/SER/mwi008

Landreth, H. ve D.C. Colander (2003). History of Economic Thought (Fourth ed.). Houghton Mifflin Company.

Lapavitsas, C. (2007). Neoliberal Dönemde Anayolcu İktisat Kuramı, Neoliberalizm. (Haz. A.S. Filho-D.Johnson), İstanbul, Yordam Kitap.

Lapavitsas, C. (2009). Financialisation Embroils Developing Countries. Discussion Paper no: 14 , August 2009. Retrieved May 4, 2010, from www.soas.ac.uk/rmf/papers/file53083.pdf

Lapavitsas, C. (2009). Financialisation, or Search for Profits in the Sphere of Circulation. Discussion Paper no:10, 11 May 2009. Retrieved May 4, 2010, from www.soas.ac.uk/rmf/papers/file51263.pdf

Lapavitsas, C. (2009). Financialised Capitalism: Crises and Financial Expropriation. Discussion Paper no:1, Department of Economics, School of Oriental and African Studies, 15 February 2009. Retrieved May 4, 2010, from www.soas.ac.uk/rmf/papers/file47508.pdf

Lind, J. (2006). The Ghent System in the Nordic Countries- Still a Vehicle for Trade Unions to Recruit Members? Industrial Relations in Europe Conference (IREC). The Future of Social Models. (Ed. M. Stanojević ve J.N. Bergoĉ). Conference Proceedings, University of Ljubljana.

Lipietz, A. (1992). Towards a New Economic Order: Post-Fordism, Ecology and Democracy (Çev. M. Slater). Oxford University Press, New York.

O'Connell, A. (2005). The Argentine Financial Crisis. In G. Epstein (Ed.), Financialization and the World Economy (pp. 289-313). Cheltenham, UK and Northampton, MA, USA: Edward Elgar.

Onaran, Ö. Stockhammer, E., \& Graftl, L. (2010). Financialization, income distribution and aggregate demand in the USA. Middlesex University Busness School, Department of Economics and Statistics, Discussion Paper no. 136, March, London, UK.

Orhangazi, Ö. (2008). Financialization and the US Economy. Edward Elgar Publishing Limited, UK.

Orhangazi, Ö. (2008, April 9). Financialisation and Capital Accumulation in the Non-Financial Corporate Sector: A Theoretical and Empirical Investigation on the US Economy: 1973-2003. Cambridge Journal of Economics, 32, 3. http://dx.doi.org/10.1093/cje/ben009

Painceira, P. J. (2009). Developing Countries in the Era of Financialisation: From Deficit Accumulation to Reserve Accumulation. Discussion Paper no 4, Department of Economics, School of Oriental and African Studies, 15 
February 2009. Retrieved May 4, 2010, from www.soas.ac.uk/rmf/papers/file47511.pdf

Palley, T. I. (2007). Financialization: What it is and Why it Matters. Political Economy Research Institute, Working Paper Series, Number 153. Retrieved from www.peri.umass.edu

Paulre, B. (2010). Crisis in the Global Economy: Financial Markets, Social Struggles, and New Political Scenarios. USA.

Sennett, R. (1998). Corrasion of Character: The Personel Consequencences of Work in the New Capitalism. W. W. Norton and Co, New York.

Skott, P., \& S. Ryoo. (2008). Macroeconomic Implications of Financialization. Working Paper, Department of Economics, University of Massachusetts, Amherst, MA.

Stockhammer, E. (2004). Financialization and the Slowdown of Accumulation. Cambridge Journal of Economics, 28(5), 719-741. http://dx.doi.org/10.1093/cje/beh032

Stockhammer, E. (2007). Some Stylized Facts on the Finance-Dominated Accumulation. unpublished manuscript, Dept. of Economics, VWI, Wirtschaftuniversitat, Wien, Austria, July 16.

Verbeek, A. (2004). A Guide to Modern Econometrics. West Sussex: John Wiley \& Sons.

Wade, H. R. (2005). The March of Neoliberalism and What to do About It. draft paper for plenary talk at conference Beyond 'Deregulation': Finance in the 21st Century, University of Sussex, 26-28 May 2005.

Wade, R. (2007). A New Global Financial Architecture? New Left Review, (46), 113-129.

Wooldridge, J. (2001). Applications of Generalized Method of Moments Estimation. Journal of Economic Perspectives, 15. http://dx.doi.org/10.1257/jep.15.4.87

\section{Notes}

Note 1. Although the sample that is used for Turkey is smaller than the samples generally used for estimations in the case of U.S.A., period under investigation is not necessarily a short one.

Note 2. Theory of Financial hierarchy explains how and why corporations with high profitability use less debt, whereas corporations with low profitability uses more debt financing, and are financialized. Highly profitable corporations do not need external funds, whereas low profitability firms prefer debt issue over issue of shares due to the fact that they cannot generate adequate amounts of internal funds and thereby require external financing and the issuing and information costs of debt financing are lower than that of issuing shares (for a detailed discussion see, Drobetz and Fix, 2003: 7)

\section{APPENDIX}

Appendix 1. Data used in research

\begin{tabular}{lll}
\hline & CODE OF CORPORATION & NAME OF CORPORATION \\
\hline 1 & ADANA & ADANA ÇIMENTO \\
2 & ADEL & ADEL KALEMCILIK \\
3 & AEFES & ANADOLU EFES \\
4 & AFYON & AFYON ÇIMENTO \\
5 & AKALT & AKAL TEKSTIL \\
6 & AKCNS & AKCANSA \\
7 & AKSA & AKSA \\
8 & ALCAR & ALARKO CARRIER \\
9 & ALKA & ALKIM KAĞIT \\
10 & ALKIM & ALKIM KIMYA \\
11 & ALTIN & ALTIN YILDIZ \\
12 & ANACM & ANADOLU CAM \\
13 & ARCLK & ARÇELIK \\
14 & ARSAN & ARSAN TEKSTIL \\
15 & ASUZU & ANADOLU ISUZU \\
16 & ATEKS & AKIN TEKSTIL \\
17 & AYGAZ & AYGAZ \\
18 & BAGFS & BAGFAS \\
19 & BAKAB & BAKAB AMBALAJ \\
20 & BANVT & BANVIT
\end{tabular}




\begin{tabular}{|c|c|c|}
\hline 21 & BFREN & BOSCH FREN \\
\hline 22 & BISAS & BISAS TEKSTİL \\
\hline 23 & BOLUC & BOLU ÇİMENTO \\
\hline 24 & BOSSA & BOSSA \\
\hline 25 & BRISA & BRISA \\
\hline 26 & BRMEN & BİRLİK MENSUCAT \\
\hline 27 & BRSAN & BORUSAN MANNESMANN \\
\hline 28 & BSHEV & BSHEV EV ALETLERİ \\
\hline 29 & BSOKE & BATISÖKE ÇİMENTO \\
\hline 30 & BTCIM & BATI ÇİMENTO \\
\hline 31 & BUCIM & BURSA ÇIMMENTO \\
\hline 32 & BURVA & BURÇELİK VANA \\
\hline 33 & CCOLA & COCA COLA İÇECEK \\
\hline 34 & CELHA & ÇELİK HALAT \\
\hline 35 & CEMTS & CEMTAS \\
\hline 36 & CIMSA & CIMSA \\
\hline 37 & CMBTN & ÇIMBBETON \\
\hline 38 & CMENT & ÇIMMENTAŞ \\
\hline 39 & DENCM & DENIZLİ CAM \\
\hline 40 & DENTA & DENTAS AMBALAJ \\
\hline 41 & DERIM & DERIMOD \\
\hline 42 & DESA & DESA DERİ \\
\hline 43 & DEVA & DEVA HOLDING \\
\hline 44 & DGZTE & DOĞAN GAZETİCİLİK \\
\hline 45 & DITAS & DİTAŞ DOĞAN \\
\hline 46 & DMSAS & DEMISAŞ DÖKÜM \\
\hline 47 & DOBUR & DOĞAN BURDA \\
\hline 48 & DOGUB & DOGUSAN \\
\hline 49 & ECILC & ECZACIBAŞI İLAÇ \\
\hline 50 & ECYAP & ECZACIBAŞI YAPI \\
\hline 51 & EGEEN & EGE ENDÜSTRİ \\
\hline 52 & EGGUB & EGE GÜBRE \\
\hline 53 & EGPRO & EGE PROFIL \\
\hline 54 & EGSER & EGE SERAMİK \\
\hline 55 & EMKEL & EMEK ELEKTRIKK \\
\hline 56 & EMNIS & EMİN İŞ AMBALAJ \\
\hline 57 & ERBOS & ERBOSAN \\
\hline 58 & EREGL & EREĞLİ DEMİR ÇELİK \\
\hline 59 & ERSU & ERSU GIDA \\
\hline 60 & FENIS & FENIŞ̧ ALÜMINNYUM \\
\hline 61 & FMIZP & F.M. İZMİT PISTON \\
\hline 62 & FRIGO & FRİGO PAK GIDA \\
\hline 63 & GENTS & GENTAŞ \\
\hline 64 & GEREL & GERSAN ELEKTRIKK \\
\hline 65 & GOLDS & GOLDAŞ KUYUMCULUK \\
\hline 66 & GOLTS & GOLTAŞ ÇİMENTO \\
\hline 67 & GOODY & GOOD YEAR \\
\hline 68 & GUBRF & GÜBRE FABRIKKALARI \\
\hline 69 & HEKTS & HEKTAŞ \\
\hline 70 & HURGZ & HÜRRIYET GAZETESİ \\
\hline 71 & HZNDR & HAZNEDAR REFRAKTER \\
\hline 72 & IDAS & İDAŞ \\
\hline 73 & IPMAT & İPEK MATBAACILIK \\
\hline 74 & IZMDC & İZMIR DEMİR ÇELİK \\
\hline 75 & IZOCM & İZOCAM \\
\hline 76 & KAPLM & KAPLAMIN \\
\hline
\end{tabular}




\begin{tabular}{|c|c|c|}
\hline 77 & KARSAN & KARSAN OTOMOTIV \\
\hline 78 & KARTN & KARTONSAN \\
\hline 79 & KERVT & KEREVITAŞ \\
\hline 80 & KLBMO & KELEBEK MOBİLYA \\
\hline 81 & KLMSN & KLİMASAN KLİMA \\
\hline 82 & KNFRT & KONFURT GIDA \\
\hline 83 & KONYA & KONYA ÇİMENTO \\
\hline 84 & KORDS & KORDSA \\
\hline 85 & KRDMD & KARDEMİR \\
\hline 86 & KRSTL & KRİSTAL KOLA \\
\hline 87 & KRTEK & KARSU TEKSTİL \\
\hline 88 & KUTPO & KÜTAHYA PORSELEN \\
\hline 89 & LUKSK & LÜKS KADİFE \\
\hline 90 & MAKTK & MAKINA TAKIM \\
\hline 91 & MEMSA & MENSA MENSUCAT \\
\hline 92 & MNDRS & MENDERES TEKSTİL \\
\hline 93 & MERKO & MERKO GIDA \\
\hline 94 & MRDIN & MARDİN ÇIMMENTO \\
\hline 95 & MRSHL & MARSHALL \\
\hline 96 & MRTGG & MERT GIDA \\
\hline 97 & MTEKS & METEMTEKS \\
\hline 98 & MUTLU & MULU AKÜ \\
\hline 99 & NUHCM & NUH ÇİMENTO \\
\hline 100 & OLMKS & OLMUKSA \\
\hline 101 & OTKAR & OTKAR \\
\hline 102 & PARSN & PARSAN \\
\hline 103 & PENGD & PENGUEN GIDA \\
\hline 104 & PETKM & PETKİM \\
\hline 105 & PETUN & PINAR ET VE UN \\
\hline 106 & PIMAS & PİMAŞ \\
\hline 107 & PINSU & PINAR SU \\
\hline 108 & PRKAB & TÜRK PRYSMIAN KABLO \\
\hline 109 & PTOFS & PETROL OFİSİ \\
\hline 110 & SARKY & SARKUYSAN \\
\hline 111 & SASA & ADVANSA SASA \\
\hline 112 & SERVE & SERVE KIRTASIYYE \\
\hline 113 & SKPLC & ŞEKER PİLİÇ \\
\hline 114 & SKTAS & SÖKTAŞ \\
\hline 115 & SNPAM & SÖNMEZ PAMUKLU \\
\hline 116 & SODA & SODA SANAYİ \\
\hline 117 & SONME & SÖNMEZ FILAMENT \\
\hline 118 & TATKS & TAT KONSERVE \\
\hline 119 & TBORG & T. TUBORG \\
\hline 120 & TOASO & TOFAŞ OTO FAB. \\
\hline 121 & TRKCM & TRAKYA CAM \\
\hline 122 & TTRAK & TÜRK TRAKTÖR \\
\hline 123 & TUDDF & T. DEMİR DÖKÜM \\
\hline 124 & TUKAS & TUKAS \\
\hline 125 & TUPRS & TUPRAŞ \\
\hline 126 & ULKER & ÜLKER BİSKUVİ \\
\hline 127 & UNYEC & ÜNYE ÇİMENTO \\
\hline 128 & USAK & UŞAK SERAMİK \\
\hline 129 & VESTL & VESTEL \\
\hline 130 & VKING & VİKİNG KAĞIT \\
\hline 131 & YATAS & YATAŞ \\
\hline 132 & YUNSA & YÜNSA \\
\hline
\end{tabular}


Appendix 2. Test results

Dependent Variable: INV2

Method: Panel Generalized Method of Moments

Transformation: First Differences

Date: 06/06/11 Time: 19:43

Sample (adjusted): 20072010

Cross-sections included: 132

Total panel (unbalanced) observations: 505

White period instrument weighting matrix

White period standard errors \& covariance (d.f. corrected)

Convergence not achieved after 500 weight iterations

Instrument list: @DYN(INV2,-2) DEBT(-1) FINPROFIT(-1) PROFIT(-1)

P SALES(-1)@SYSPER

$\begin{array}{lllll}\text { Variable } & \text { Coefficient } & \text { Std. Error } & \text { t-Statistic } & \text { Prob. } \\ & & & & \\ \text { INV2(-1) } & 0.624275 & 0.003852 & 162.0549 & 0.0000 \\ \text { DEBT(-1) } & 0.013769 & 0.009781 & 1.407709 & 0.1598 \\ \text { FINPROFIT(-1) } & -0.049034 & 0.018685 & -2.624257 & 0.0090 \\ \text { PROFIT(-1) } & 0.004245 & 0.016896 & 0.251255 & 0.8017 \\ \text { P } & -0.047736 & 0.025966 & -1.838403 & 0.0666 \\ \text { SALES(-1) } & 0.006666 & 0.003894 & 1.711843 & 0.0876 \\ \text { @ISPERIOD("2007") } & -0.015637 & 0.011937 & -1.309988 & 0.1908 \\ \text { @ISPERIOD("2008") } & -0.039553 & 0.011920 & -3.318294 & 0.0010 \\ \text { @ISPERIOD("2009") } & -0.075203 & 0.014328 & -5.248600 & 0.0000 \\ \text { @ISPERIOD("2010") } & -0.036177 & 0.015221 & -2.376795 & 0.0178\end{array}$

Effects Specification

Cross-section fixed (first differences)

Period fixed (dummy variables)

$\begin{array}{llll}\text { R-squared } & 0.433778 & \text { Mean dependent var } & 0.014493 \\ \text { Adjusted R-squared } & 0.459846 & \text { S.D. dependent var } & 1.946489 \\ \text { S.E. of regression } & 2.351828 & \text { Sum squared resid } & 2737.892 \\ \text { J-statistic } & 3.561606 & \text { Instrument rank } & 19.00000\end{array}$


Appendix 3. Test results

Dependent Variable: INV2

Method: Panel Generalized Method of Moments

Transformation: First Differences

Date: 06/06/11 Time: 19:51

Sample (adjusted): 20072010

Cross-sections included: 132

Total panel (unbalanced) observations: 505

White period instrument weighting matrix

White period standard errors \& covariance (d.f. corrected)

Convergence not achieved after 500 weight iterations

Instrument list: @DYN(INV2,-2) DEBT(-1) FINPROFIT(-1) PROFIT(-1)

P@SYSPER

$\begin{array}{lllll}\text { Variable } & \text { Coefficient } & \text { Std. Error } & \text { t-Statistic } & \text { Prob. } \\ & & & & \\ \text { INV2(-1) } & 0.630290 & 0.003673 & 171.5890 & 0.0000 \\ \text { DEBT(-1) } & 0.021565 & 0.008941 & 2.411823 & 0.0162 \\ \text { FINPROFIT(-1) } & -0.045020 & 0.018080 & -2.489976 & 0.0131 \\ \text { PROFIT(-1) } & 0.012183 & 0.016147 & 0.754465 & 0.4509 \\ \text { P } & -0.049063 & 0.026069 & -1.882016 & 0.0604 \\ \text { @ISPERIOD("2007") } & -0.014273 & 0.012100 & -1.179607 & 0.2387 \\ \text { @ISPERIOD("2008") } & -0.036728 & 0.011715 & -3.135264 & 0.0018 \\ \text { @ISPERIOD("2009") } & -0.075095 & 0.014419 & -5.208065 & 0.0000 \\ \text { @ISPERIOD("2010") } & -0.037292 & 0.015620 & -2.387429 & 0.0173\end{array}$

Effects Specification

Cross-section fixed (first differences)

Period fixed (dummy variables)

$\begin{array}{llll}\text { R-squared } & 0.443029 & \text { Mean dependent var } & 0.014493 \\ \text { Adjusted R-squared } & 0.466304 & \text { S.D. dependent var } & 1.946489 \\ \text { S.E. of regression } & 2.357024 & \text { Sum squared resid } & 2755.558 \\ \text { J-statistic } & 3.841951 & \text { Instrument rank } & 18.00000\end{array}$

